\title{
Budidaya dan Pengolahan Jahe Merah (Zingiber officinale var.rubrum) Menggunakan Teknologi Bag Culture Pada Masa New Normal di Desa Darmaraja Kecamatan Lumbung Kabupaten Ciamis
}

\author{
Nana1, Yanti Sofi Makiyah², Ernita Susanti ${ }^{3}$, Ilham Rohman Ramadhan ${ }^{4}$, Revanika \\ Yusman Bhinekas ${ }^{5}$, Luthviana Kanti ${ }^{6}$ \\ 1,2,3,5,6 Jurusan Pendidikan Fisika, Fakultas Keguruan dan Ilmu Pendidikan, Universitas Siliwangi, \\ Tasikmalaya 46115, Indonesia \\ ${ }^{4}$ Jurusan Pendidikan Sejarah, Fakultas Keguruan dan IImu Pendidikan, Universitas Siliwangi, \\ Tasikmalya 46115, Indonesia. \\ email: nana@unsil.ac.id
}

\begin{abstract}
Abstrak
Jahe merah dengan nama latin Zingiber officinale var. Rubrum memiliki kandungan minyak atsiri sebesar 2,58-2,72\%. Selain itu, kandungan senyawa kimia aktif seperti gingerol, zingeron, shogaol, gingerin dan zingerberin dalam jahe merah menyebabkan jahe merah memiliki khasiat yang besar untuk kesehatan. Kegiatan pengabdian ini dilakukan kepada masyarakat di Desa Darmaraja, Kecamatan Lumbung, Kabupaten Ciamis. Tujuan dari kegiatan pengabdian ini adalah untuk memberikan penyuluhan budidaya dan pengolahan tanaman jahe merah dengan menggunakan teknologi bag culture, yaitu sistem bertanam di dalam karung bekas atau polybag besar. Budidaya dan pengolahan jahe merah juga dilakukan untuk menumbuhkan semangat masyarakat dalam memanfaatkan pekarangan rumah. Metode yang dilakukan adalah dengan cara pelatihan budidaya dan pengolahan tanaman jahe merah. Setelah pelatihan dilaksanakan, terjadi peningkatan pengetahuan masyarakat mengenai penanaman Jahe Merah dengan teknologi bag culture. Masyarakat memberikan respons yang sangat positif terhadap kegiatan yang telah dilaksanakan dan menilai kegiatan ini sangat bermanfaat. Selain itu, kegiatan ini dapat mendorong kemandirian ekonomi mitra dengan memanfaatkan jahe merah yang ditanam di pekarang untuk diolah menjadi bubuk jahe yang dapat dikonsumsi baik secara pribadi atau dijual secara komersial.
\end{abstract}

Kata kunci: jahe merah, Darmaraja, bag culture, new normal

\begin{abstract}
Red ginger with the Latin name Zingiber officinale var. Rubrum has an essential oil content of 2.58$2.72 \%$. In addition, the content of active chemical compounds such as gingerol, zingeron, shogaol, gingerin and zingerberin in red ginger causes red ginger to have great health benefits. This activity is carried out to the community in Darmaraja Village, Lumbung District, Ciamis Regency. The purpose of this activity is to provide counseling on the cultivation and processing of red ginger plants using bag culture technology, which is a system of planting in used sacks or large polybags. Cultivation and processing of red ginger are also carried out to foster community enthusiasm in utilizing house yards. The method used is by training the cultivation and processing of red ginger plants. After the training was carried out, there was an increase in people's knowledge about planting red ginger using bag culture technology. The community gave a very positive response to the activities that have been implemented and considered this activity very useful. In addition, this activity can encourage the economic independence of partners by utilizing red ginger grown in house yard to be processed into ginger powder which can be consumed either personally or commercially.
\end{abstract}

Keywords: red ginger, Darmaraja, bag culture, new normal

\section{PANDAHULUAN}

Pandemi Covid-19 menimbulkan tantangan yang signifikan bagi kehidupan manusia secara global. Salah sektor yang paling terdampak adalah ekonomi masyarakat. Para ekonom global memprediksi, tahun ini tidak ada negara yang akan mencapai target pertumbuhan ekonomi yang positif, akibat dari tersendatnya produksi, dan penurunan konsumsi akibat aktivitas masyarakat dibatasi untuk mencegah penularan Covid-19. Oleh karena itu 
masyarakat harus dapat memanfaatkan potensi dan peluang usaha yang ada saat ini. Salah satu peluang usaha yang dapat dimanfaatkan yaitu berkaitan dengan upaya peningkatan daya tahan tubuh baik secara konvensional maupun tradisional. Secara tradisional, salah satu peningkat daya tahan tubuh alami adalah dengan mengonsumsi rimpang yang mengandung curcumin sebagai komponen utama minyak asiri. Salah satu bahan alami yang mengandung curcumin adalah jahe merah.

Jahe merah dengan nama latin Zingiber officinale var. Rubrum memiliki kandungan minyak atsiri 2,58 - 2,72\%. Selain itu, kandungan senyawa kimia aktif gingerol, zingeron, shogaol, gingerin dan zingerberin dalam jahe merah menyebabkan jahe merah memiliki khasiat yang besar untuk kesehatan (Triyono \& Sumarni, 2018). Oleh karena itu, jahe merah menjadi salah satu tanaman herbal yang paling banyak dicari karena diyakini berkhasiat memperkuat imunitas atau daya tahan tubuh. Hal ini berdampak pada tingginya permintaan jahe merah di pasaran. Meningkatnya permintaan pasar, petani pun di tuntut untuk lebih optimal meningkatkan jumlah luas tanam demi menutup permintaan tersebut.

Tanaman jahe dapat tumbuh baik pada daerah dengan tipe iklim A, B, C dan curah hujan antara 2500-4000 mm/tahun dengan 7-9 bulan basah per tahun. Tanaman jahe dapat dibudidayakan pada daerah yang memiliki ketinggian 0-1500 m dpl dengan ketinggian optimum pada 300-900 m dpl. Desa Darmaraja, Kecamatan Lumbung Kabupaten Ciamis merupakan daerah dengan tipe iklim $\mathrm{C}$ dan terletak pada ketinggian $580 \mathrm{~m}$ dpl (BPS Kab. Ciamis, 2016). Desa Darmaraja memiliki curah hujan yang cukup tinggi yaitu 10 bulan basah dalam satu tahun dan memiliki tanah yang subur serta masyarakatnya mayoritas sebagai petani, sehingga memiliki potensi yang baik untuk budidaya jahe.

Berdasarkan kondisi tersebut, budidaya dan pengolahan tanaman jahe merah di Desa Darmaraja dapat dilakukan untuk memenuhi permintaan jahe merah di pasaran. Budidaya tanaman jahe dilakukan menggunakan teknologi bag culture dengan menggunakan sistem bertanam didalam karung bekas atau polybag besar. Budidaya dan pengolahan jahe merah juga dilakukan untuk menumbuhkan semangat masyarakat dalam mengembangkan dan mengoptimalkan penggunaan pekarangan rumah. Selain itu, masih banyak masyarakat yang belum memahami peluang jahe merah di pasaran saat ini sehingga masyarakat di Desa Darmaraja belum terlalu tertarik melakukan budidaya tanaman jahe merah dan mengolahnya menjadi produk yang siap dijual di pasaran. Oleh karena itu, perlu diadakan pengabdian kepada masyarakat yang dapat memberikan pemahaman mengenai hal tersebut.

Berdasarkan hasil analisis situasi Desa Darmaraja didapatkan permasalahan mitra sebagai berikut:

1. Kurang maksimalnya informasi mengenai manfaat tanaman jahe merah pada masa pandemi Covid-19.

2. Belum adanya penyuluhan bagi petani tentang budidaya dan pengolahan tanaman jahe merah

3. Masyarakat Desa Darmaraja mayoritas adalah petani dan rata-rata memiliki lahan namun belum memaksimalkan penggunaan lahan tersebut untuk budidaya tanaman yang bernilai ekonomis

4. Target dan luaran dari kegiatan Pengabdian bagi Masyarakat pada Skema Ketahanan Pangan (PbM-KP) adalah masyarakat di Desa Darmaraja Kecamatan Lumbung Kabupaten Ciamis mampu melakukan budidaya tanaman jahe merah menggunakan teknologi bag culture dan mengolahnya menjadi produk setengah jadi seperti jahe merah serbuk.

Kontribusi yang diharapkan dari kegiatan pengabdian kepada masyarakat ini adalah meningkatkan perekonomian masyarakat sekaligus daya tahan tubuh menghadapi situasi new normal ini. Kegiatan ini juga diharapkan dapat membantu warga mengatasi masalah keterbatasan lahan untuk bercocok tanam jahe, karena dengan diperkenalkannya Teknik bag culture ini, masyarakat dapat memanfaatkan pekarangan dan lahan terbatas lainnya. 


\section{METODE PELAKSANAAN}

Hasil studi lapangan dan wawancara dengan mitra digunakan sebagai bahan tindak lanjut pengkajian terhadap masalah yang dimiliki mitra. Berdasarkan hasil kajian masalah, maka yang menjadi prioritas masalah utama mitra adalah bagaimana cara budidaya dan pengolahan tanaman jahe merah menggunakan teknologi bag culture pada masa new normal di Desa Darmaraja Kecamatan Lumbung Kabupaten Ciamis sebagai upaya memaksimalkan penggunaan lahan untuk menanam tanaman yang bernilai ekonomis.

Pada dasarnya sistem bag culture adalah pembudidayaan tanaman dengan menggunakan sistem bertanam di dalam karung bekas atau polybag besar. Sistem budidaya jahe dalam karung ini telah dikembangkan di Hawaii sejak tahun 2004 (Hepperly dan Francis, 2017). Di Indonesia sendiri pembudidayaan dengan cara ini telah dilakukan oleh beberapa pihak, baik institusi maupun individu, salah satunya oleh Balai Penelitian Tanaman Rempah dan Obat (Balittro). Dibandingkan dengan sistem penanaman konvensional, Sistem bag culture ini memiliki beberapa keunggulan, yang diantaranya adalah; dapat dilakukan di lahan yang terbatas, hemat dalam penggunaan air, tidak perlunya mengatur sistem drainase, kondisi tanah lebih terkontrol, karena setiap tanaman berada di karung yang berbeda, sehingga dapat meminimalkan serangan hama dan penyakit, dan produksinya lebih tinggi. (Zuhro, 2018).

Pelaksanaan budidaya jahe merah dengan menggunakan sistem bag culture dibagi kedalam empat tahap yang terdiri dari tahap lokakarya (workshop) dan sosialisasi, pembibitan dan penyemaian, pemeliharaan, serta Penanaman.

Untuk mencapai target yang diharapkan, program kemitraan ini dilakukan melalui metode pelaksanaan sebagai berikut:

1. Tahap persiapan, merupakan perencanaan program pengabdian yang meliputi: (a) melakukan survei lapangan, (b) penetapan sasaran dan target peserta pelatihan, (c) penetapan lokasi dan waktu pelatihan dan (d) perencanaan materi pelatihan

2. Tahap pelaksanaan yaitu berupa kegiatan pelatihan tentang budi daya tanaman jahe merah menggunakan teknologi bag culture untuk meningkatkan pengetahuan masyarakat tentang khasiat jahe, tata cara menanam jahe merah untuk memenuhi permintaan jahe merah di pasaran, serta meningkatkan keterampilan masyarakat dalam mengolah jahe merah guna memanfaatkan peluang jahe merah di pasaran saat ini

Kegiatan pengabdian masyarakat berupa budidaya dan pengolahan tanaman jahe menggunakan teknologi bag culture sebagai upaya memaksimalkan penggunaan lahan untuk menanam tanaman yang bernilai ekonomis. Media yang digunakan dalam kegiatan ini berupa power point dan booklet. Adapun metode yang digunakan adalah ceramah disertai dengan praktik. Pada kegiatan ini juga dilakukan sesi diskusi dan tanya jawab

Secara rinci keempat tahap tersebut dijelaskan sebagai berikut:

1. Lokakarya dan sosialisasi

Tahap pertama dimulai dengan memberikan informasi kepada masyarakat terkait dengan proses budidaya jahe merah dengan sistem bag culture, yang meliputi karakteristik tanaman jahe merah, khasiat atau kegunaan, pengolahan pasca panen dan peluang usahanya.

2. Pembibitan dan penyemaian

Tahap kedua adalah pembibitan, yang dimulai dengan proses pemilihan atau seleksi rimpang jahe merah. Rimpang jahe merah yang akan dipilih memiliki kriteria tertentu, diantaranya ialah berukuran besar dan keras, tidak ada luka atau goresan, serta bersih dari hama yang berupa bercak putih (Rahman, 2009). Rimpang jahe merah yang dipilih berasal dari jahe merah yang berusia kurang lebih satu tahun. Setelah dilakukan seleksi, rimpang jahe merah selanjutnya dicuci hingga bersih dan direndam dalam larutan fungisida dan bakterisida selama 30 menit (Supriyanti, 2015). Proses ini bertujuan untuk mencegah tumbuhnya patogen yang sering menyerang, seperti: Ralstonia solanacearum, Erwinia, Fusarium, dan berbagai patogen lainnya (Stirling, 2002; Inden, 1988). 
Selanjutnya, rimpang jahe merah dipotong-potong sebanyak 3 ruas atau sekitar 2,5$5 \mathrm{~cm}$, masing-masing potongan rimpang harus ada tonjolan mata tunas yang berwarna putih (Bahret, 2008; Geta, 2011). Potongan rimpang kemudian ditanam di dalam pot-tray. Sebelumnya di dalam pot-tray telah ditambahkan media tanam yang terdiri dari serabut/moss, sekam bakar, dan kompos dengan perbandingan 1:1:1. Potongan rimpang yang telah ditanam di dalam pot-tray dipelihara di greenhouse atau tempat yang ternaungi.

Kegiatan pembibitan ini dilakukan selama kurang lebih 30 hari hingga rimpang jahe memunculkan tunas dengan panjang sekitar $15 \mathrm{~cm}$ (ICAR, 2015; Prasath, 2016). Selama periode itu, bibit harus dipelihara dengan cara melakukan penyiraman reguler dan pembumbuan secara berkala.

3. Pemeliharaan

Tahap ketiga, setelah dilakukan proses penyemaian, bibit jahe merah akan masuk kedalam tahap pemeliharaan yang dilakukan dengan memindahkan bibit jahe merah dari pot-tray kedalam polybag. Tahap ini dimulai dari proses seleksi bibit terlebih dahulu. Bibit dipisahkan berdasarkan ukuran dan kondisi tunas karena tidak semua tunas tumbuh secara sama (Supriyanti, 2015). Lalu, bibit dikeluarkan dari pot-tray dan dipindahkan kedalam polybag yang telah berisi media tanam. Media tanam yang digunakan di tahap pemeliharaan terdiri dari humus, tanah dan sekam dengan perbandingan 1:1:1.

4. Penanaman di Karung

Tahap terakhir dari budidaya jahe merah ialah proses penanaman bibit jahe di karung. langkah pertama yang harus dilakukan ialah mempersiapkan karung yang akan digunakan. Tanah yang akan digunakan di dalam karung telah dicampur dengan pupuk kendang, cocopet dan serbuk kayu terlebih dahulu. Gulung karung sampai ketinggian yang sesuai dengan bibit jahe merah. Proses penanaman jahe merah di awal penanaman membutuhkan curah hujan yang tinggi sehingga waktu optimal penanamannya dimulai pada pertengahan atau akhir musim penghujan (Geta, 2011). Hal ini bisa dibantu juga dengan proses penyiraman secara manual. Sedangkan jika usia jahe merah sudah menginjak 5 bulan, pengairan harus dikurangi dan sebaliknya diperbanyak sinar matahari, karena pada usia ini jahe merah memfokuskan pertumbuhan rimpangnya. Selama penanaman hingga masa panen, tanaman jahe harus dirawat dan rutin dilakukan penyulaman, penyiangan, dan pembumbunan. Penyulaman dilakukan dengan cara mengganti dan menyingkirkan bibit jahe merah yang tidak tumbuh, rusak, atau mati. Penyiangan tanaman jahe merah dilakukan dengan menghilangkan gulma serta tanaman lain yang dapat mengganggu pertumbuhan tanaman. Dilain sisi juga dilakukan pembumbunan dengan cara menggemburkan dan menaikkan Kembali tanah-tanah yang turun atau longsor dari bedengan yang ada. Hal ini bertujuan untuk menutup kembali pangkal batang tanaman sehingga tanaman menjadi lebih kuat. Disamping itu, perlu juga dilakukan penyiraman serta pemupukan secara berkala.

5. Selanjutnya proses pengolahan jahe merah dilakukan untuk mengubah bahan mentah menjadi bentuk lain yang dapat dikonsumsi. Jahe merah paling umum diolah menjadi bentuk serbuk, hal ini bertujuan untuk memudahkan dalam mengonsumsinya. Proses pengolahan jahe merah ini dapat dipadukan dengan bahan alami lain untuk menambah cita rasa yang ingin diperoleh. Dalam usulan pengabdian ini penulis mengembangkan proses pengolahan sederhana yang dapat dilakukan dalam skala rumah tangga.

\section{HASIL DAN PEMBAHASAN}

Kegiatan pengabdian kepada masyarakat ini dapat diuraikan melalui dua tahap kegiatan, yaitu tahap persiapan dan tahap pelaksanaan. Tahap persiapan merupakan tahap perencanaan program pengabdian, yang terdiri dari:

1. Melakukan survei lapangan 
Survei lapangan dilakukan untuk melakukan koordinasi dengan pihak desa Darmaraja, Kabupaten Ciamis. Koordinasi dilakukan dengan bapak Oo Nuryana dan bapak Iding yang bersedia menjadi mitra. Pihak desa mendukung kegiatan pengabdian yang dilakukan oleh tim pengabdian.

2. Penetapan sasaran dan target peserta pelatihan

Dari koordinasi dengan pihak desa, maka diputuskan sasaran pelatihan budi daya tanaman jahe yaitu warga desa Darmaraja Kabupaten Ciamis, yaitu dengan target peserta pelatihan sebanyak 30 orang.

3. Penetapan lokasi dan waktu pelatihan

Berdasarkan hasil koordinasi dengan mitra, maka pelaksanaan pelatihan budidaya jahe merah dilakukan pada hari Sabtu, tanggal 10 Oktober 2020.

4. Perencanaan materi pelatihan

Materi pelatihan disosialisasikan oleh ahli pertanian yaitu Bapak. Dr. Suhardjadinata, Ir. M.P. Materi pelatihan yang direncanakan oleh tim pengabdian meliputi pengetahuan tentang khasiat tanaman jahe merah, tata cara penanaman jahe merah serta pengolahan tanaman jahe merah.

Setelah tahap persiapan, selanjutnya diikuti dengan tahap pelaksanaan. Pada tahap pelaksanaan. Pelatihan budi daya tanaman jahe merah menggunakan teknologi bag culture pada masa new normal di Desa Darmaraja Kabupaten Ciamis dilaksanakan pada hari Sabtu, tanggal 10 Oktober 2020 di halaman rumah Bapak Oo Nuryana. Kegiatan pengabdian dihadiri oleh 30 orang peserta yang di undang berdasarkan arahan dari mitra. Para peserta dapat memahami materi pelatihan dengan baik dan antusias ketika melakukan praktik menanam jahe merah. Adapun materi pelatihan yang disampaikan yaitu:

a. Pengetahuan tentang jenis-jenis jahe yang biasa dimanfaatkan sebagai bumbu dapur maupun obat tradisional. Adapun jenis-jenis jahe yang biasa dimanfaatkan yaitu jahe merah, jahe putih besar dan jahe putih kecil. Rimpang jahe mengandung Minyak atsiri Zingiberena/Zingirona, Zingiberol, Bisabolena, Kurkumen, Gingerol, Filandera, resin pahit, yang bermanfaat untuk meningkatkan kekebalan tubuh, obat mulas, sakit kepala, melancarkan ASI untuk ibu yang menyusui dan salesma atau Influeza.

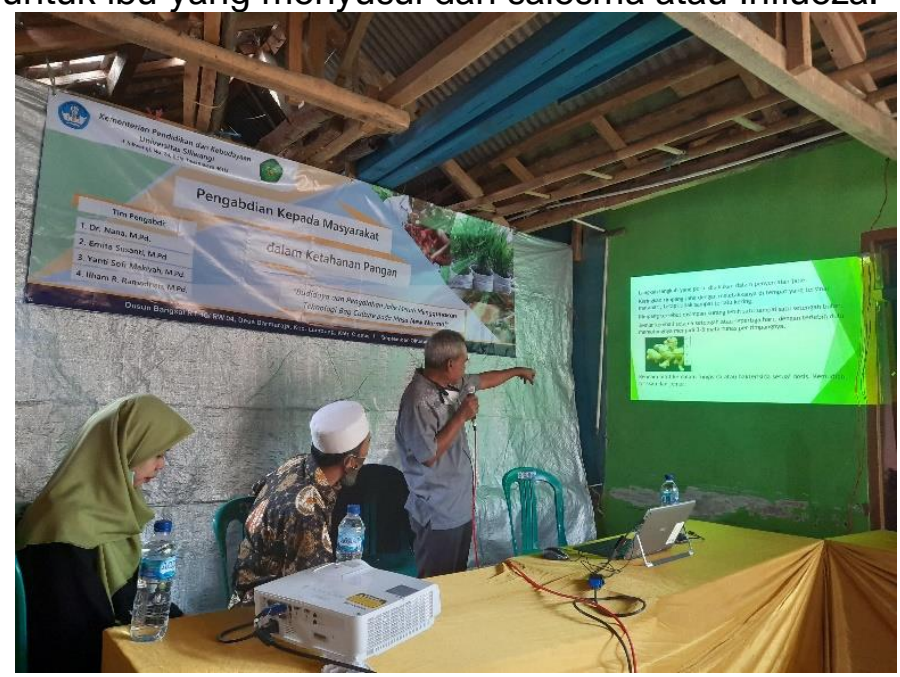

Gambar 1. Materi mengenai pengetahuan jenis jahe serta manfaatnya

b. Langkah-langkah budidaya jahe merah menggunakan teknologi bag culture. Budidaya jahe merah dengan menggunakan teknologi bag culture atau yang lebih dikenal dengan penanaman jahe di polybag atau karung ini dinilai lebih praktis karena tidak memerlukan pembuatan bedengan dan juga tidak menghabiskan banyak tempat atau lahan yang dipakai. Disamping itu penanaman jahe pada polybag/karung menyebabkan pertumbuhan jahe lebih cepat daripada di tanah lapang/di tegalan adapun langkah-langkah penanaman yaitu dimulai dengan menyemai bibit jahe agar cepat tumbuh, menyiapkan media tanam, menanam jahe, melakukan pemeliharaan dan panen. 
Semua materi tersebut dapat disampaikan oleh pemateri dengan jelas dan sangat baik. Setelah pemaparan, selanjutnya dibuka sesi tanya jawab. Pada sesi tanya jawab ada beberapa pertanyaan yang diajukan peserta, antara lain: apa yang harus dilakukan jika tanaman jahe terserang penyakit, bagaimana peluang budidaya jahe merah, dan bagaimana solusi agar tanaman jahe tersebut baik.

c. Setelah pemaparan materi dan sesi tanya jawab, dilakukan demonstrasi cara menanam jahe merah dengan teknologi bag culture. Pada proses ini diberikan juga beberapa bibit jahe merah dan media tanam untuk dibudidayakan di lokasi pengabdian. Bibit jahe yang diberikan yaitu jahe merah yang sudah memiliki tunas. Demonstrasi dimulai dari penyiapan karung yang akan digunakan sebagai wadah untuk menanam jahe. Selanjutnya pemateri mendemonstrasikan perbandingan media tanam yang akan digunakan. Media tanam yang digunakan yaitu tanah, pupuk kandang, cocopet dan serbuk gergaji, dengan perbandingan 2:1:1:1. Setelah menyiapkan media tanam, pemateri menginstruksikan bahwa media tanam tersebut harus di didiamkan selama satu sampai dua minggu setelah itu media tanam siap digunakan untuk menanam jahe. Selama proses demonstrasi peserta sangat antusias dan memperhatikan pemateri dengan cermat. Setelah itu peserta dipersilahkan untuk menyiapkan media tanam mereka sendiri dengan perbandingan 2:1:1:1 kemudian media tanam tersebut disimpan dalam waktu seminggu atau dua minggu.

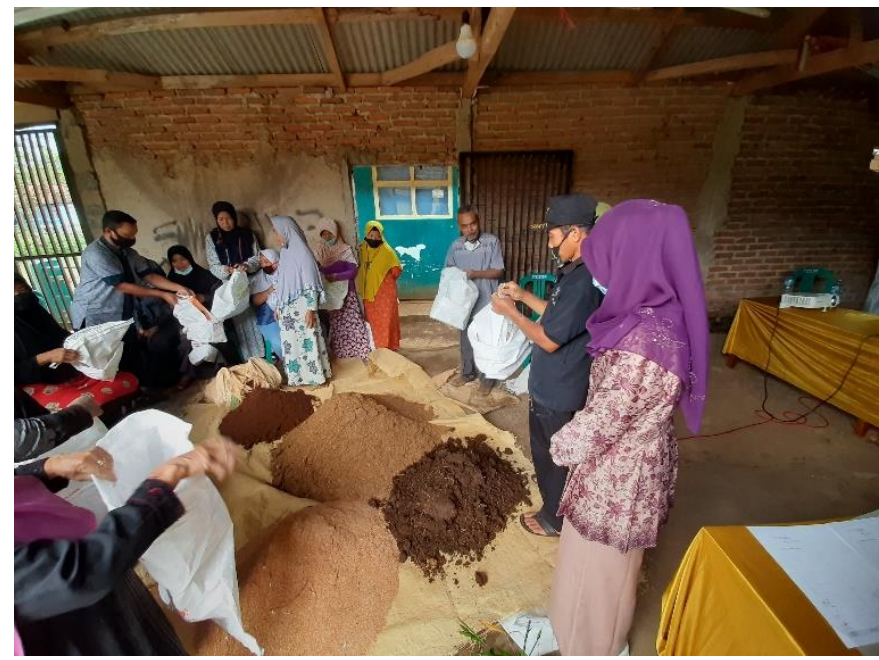

Gambar 2. Demonstrasi penanaman jahe merah dengan system bag culture

Untuk melihat tingkat kepuasan peserta pelatihan, maka dilakukan analisis kepuasan peserta menggunakan skala likert dengan 5 kategori penilaian. Analisis dilakukan terhadap materi kegiatan, implikasi kegiatan terhadap pengetahuan dan keterampilan, serta analisis terhadap kesiapan dan kinerja tim pengabdian. Distribusi hasil analisis materi kegiatan dapat dilihat pada Tabel 4.

Tabel 1. Hasil Analisis Materi Kegiatan

\begin{tabular}{|c|l|c|c|}
\hline No. & \multicolumn{1}{|c|}{ Pernyataan } & Nilai & Kategori \\
\hline 1 & $\begin{array}{l}\text { Materi kegiatan budidaya dan pengolahan tanaman } \\
\text { jahe merah menggunakan teknologi Bag Culture } \\
\text { merupakan hal yang baru bagi saya. }\end{array}$ & 81 & Baik \\
\hline 2 & Materi kegiatan jelas dan mudah dipahami & 83 & Baik \\
\hline 3 & $\begin{array}{l}\text { Kualitas materi kegiatan dapat menambah tingkat } \\
\text { keterampilan dan pengetahuan saya }\end{array}$ & 84 & Baik \\
\hline
\end{tabular}




\begin{tabular}{|c|l|c|c|}
\hline 4 & $\begin{array}{l}\text { Materi yang diberikan dapat membantu saya untuk } \\
\text { membudidayakan jahe dalam kehidupan sehari- } \\
\text { hari. }\end{array}$ & 81 & Baik \\
\hline Rata-rata & 82,25 & Baik \\
\hline
\end{tabular}

Berdasarkan tabel diatas dapat disimpulkan, materi yang disajikan baik. Materi yang disajikan merupakan hal yang baru bagi masyarakat, materi yang disajikan mudah dipahami dan dapat menambah pengetahuan dan keterampilan masyarakat dalam membudidayakan jahe merah di kehidupan sehari-hari.

Hasil analisis implikasi kegiatan terhadap pengetahuan dan keterampilan peserta dapat dilihat pada Tabel 5.

Tabel 2. Hasil Analisis Implikasi Kegiatan

\begin{tabular}{|c|l|c|c|}
\hline No. & Pernyataan & Nilai & Kategori \\
\hline 1 & Saya merasa antusias mengikuti kegiatan ini. & 82 & Baik \\
\hline 2 & $\begin{array}{l}\text { Kegiatan ini benar-benar sesuai dengan kebutuhan } \\
\text { pada masa New Normal }\end{array}$ & 78 & Baik \\
\hline 3 & $\begin{array}{l}\text { Kegiatan ini memotivasi saya untuk } \\
\text { membudidayakan jahe merah menggunakan } \\
\text { teknologi Bag Culture }\end{array}$ & 84 & Baik \\
\hline \multicolumn{2}{|l|}{ Rata-rata } & 81 & Baik \\
\hline
\end{tabular}

Berdasarkan tabel diatas dapat disimpulkan, implikasi kegiatan terhadap pengetahuan dan keterampilan peserta dapat dikategorikan baik, dengan rata-rata nilai 81 . Hal tersebut dapat dilihat dari antusiasnya peserta ketika mengikuti pelatihan, selain itu kegiatan ini dapat memotivasi peserta pelatihan untuk membudidayakan jahe merah dengan menggunakan teknologi bag culture.

Selanjutnya hasil analisis kesiapan dan kinerja tim pengabdian dapat dilihat pada Tabel 7.

Tabel 3. Hasil Analisis Kesiapan Dan Kinerja Tim Pengabdian

\begin{tabular}{|c|c|c|c|}
\hline No. & \multicolumn{1}{|c|}{ Pernyataan } & Nilai & Kategori \\
\hline 1 & \multicolumn{1}{|c|}{$\begin{array}{c}\text { Tim pengabdian memahami materi kegiatan } \\
\text { dengaik }\end{array}$} & 83 & Baik \\
\hline 2 & $\begin{array}{l}\text { Tim pengabdian mampu mentransfer materi kepada } \\
\text { peserta sehingga sasaran yang diinginkan tercapai }\end{array}$ & 81 & Baik \\
\hline 3 & $\begin{array}{l}\text { Tim pengabdian cepat tanggap dalam membantu } \\
\text { kesulitan-kesulitan yang dialami peserta kegiatan. }\end{array}$ & 81 & Baik \\
\hline 4 & $\begin{array}{l}\text { Pengetahuan, kualitas keramahtamahan, perhatian, } \\
\text { dan sikap tim pengabdian selama kegiatan sudah } \\
\text { baik. }\end{array}$ & 81 & Baik \\
\hline 5 & $\begin{array}{l}\text { Kualitas sarana dan prasarana, serta penampilan } \\
\text { tim pengabdian sudah baik }\end{array}$ & 83 & Baik \\
\hline Rata-rata & $\mathbf{8 1}$ & Baik \\
\hline
\end{tabular}

Berdasarkan tabel diatas dapat disimpulkan, kesiapan dan kinerja tim pengabdian dapat dikategorikan baik dengan rata-rata nilai 81. Hal ini dapat dilihat dari tim pengabdian memahami materi kegiatan, tim pengabdian cepat tanggap dalam membantu kesulitankesulitan yang dialami peserta kegiatan, kemudian keramahtamahan, perhatian, dan sikap tim pengabdian selama kegiatan sudah baik dan kualitas sarana dan prasarana, serta penampilan tim pengabdian sudah baik

Setelah melakukan pelatihan bagaimana cara budidaya jahe merah menggunakan karung, tahapan berikutnya yang akan dilakukan yaitu observasi lapangan dan pengambilan data tanaman jahe yang sudah ditanam. Observasi dan pengambilan data dilakukan 
sebanyak 4 kali kunjungan. Setelah observasi dan pengambilan data, selanjutnya dilakukan pelatihan yang kedua tentang pengolahan jahe merah menjadi serbuk jahe instan yang dikemas dengan packaging yang menarik, praktis dan ekonomis.

Pengolahan dilakukan di halaman rumah Bapak Oo Nuryana. Kegiatan pengolahan dihadiri oleh 13 orang ibu-ibu yang di undang berdasarkan arahan dari mitra. Alat yang digunakan untuk mengolah jahe merah yaitu pisau, blender, kain, wajan, kompor dan timbangan. Adapun bahan yang dibutuhkan untuk pengolahan jahe merah yaitu jahe merah, gula pasir, air, kayu manis dan cengkih. Pengolahan jahe merah dikerjakan bersama-sama agar selesai tepat waktu karena waktu pengolahan sangat mempengaruhi bubuk jahe yang dihasilkan (Ibrahim, Yunianta and Sriherfyna, 2014).

Proses pengolahan jahe dimulai dari bahan mentah hingga menjadi serbuk jahe instan yang dikemas dengan packaging yang menarik, praktis dan ekonomis serta siap diseduh menggunakan air hangat. Adapun langkah-langkah pengolahan jahe yang dilakukan yaitu:

1. Mengiris tipis jahe merah yang sudah dicuci dengan bersih.

2. Memasukkan jahe dan menambahkan air ke blender untuk dihaluskan.

3. Jahe diperas menggunakan kain kemudian didiamkan kurang lebih 30 menit agar patinya mengendap.

4. Memasukkan jahe yang telah didiamkan tanpa pati yang mengendap ke dalam wajan.

5. Memasukkan cengkeh dan kayu manis.

6. Memanaskan wajan dan mengaduk wajan sampai cairan jahe menjadi kental.

7. Mematikan kompor, dan mengaduk sampai berbentuk serbuk.

8. Menuangkan olahan jahe pada wadah untuk didinginkan.

9. Mengemas olahan jahe dan menimbang massanya.
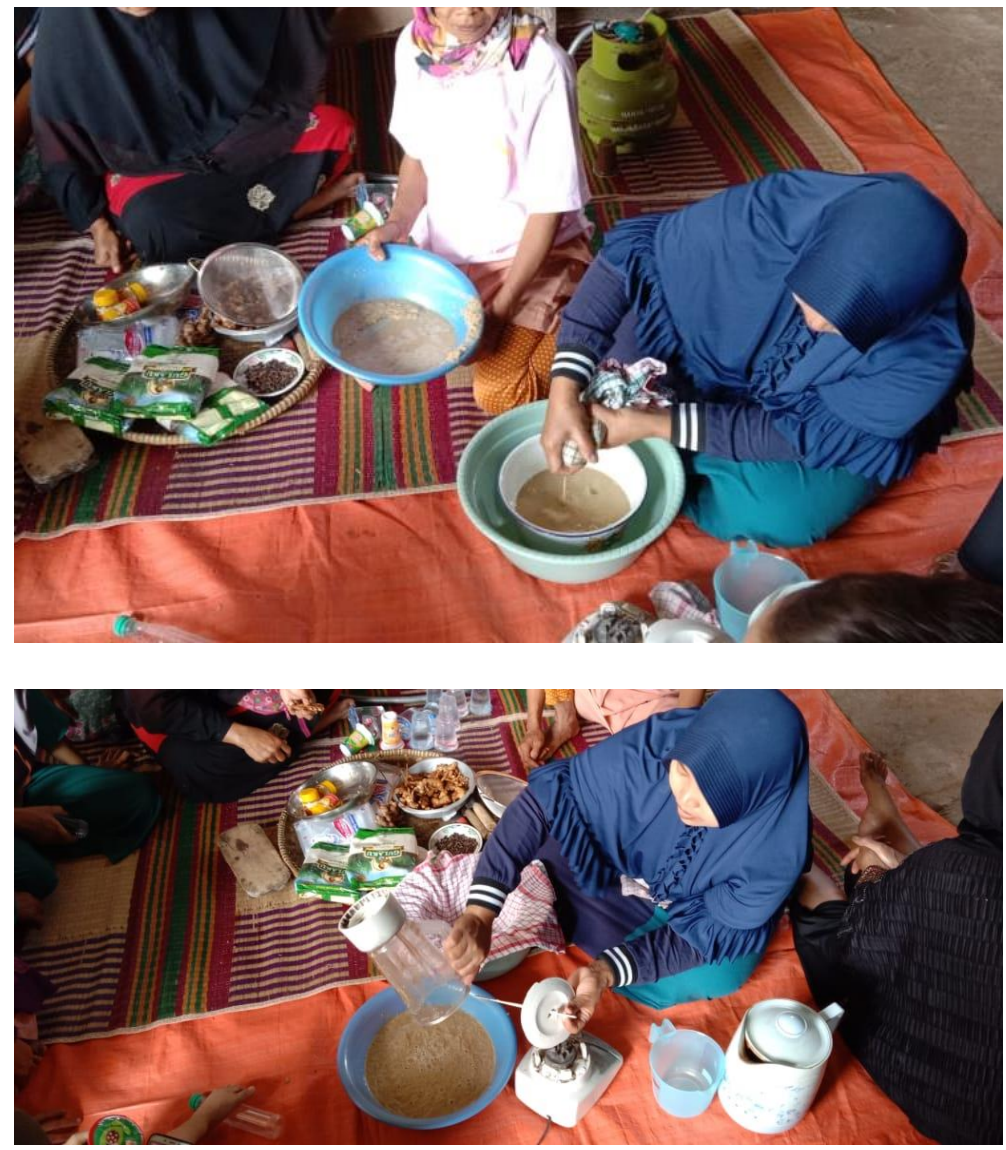

Gambar 3. Proses pengolahan jahe dengan cara dihaluskan terlebih dahulu 

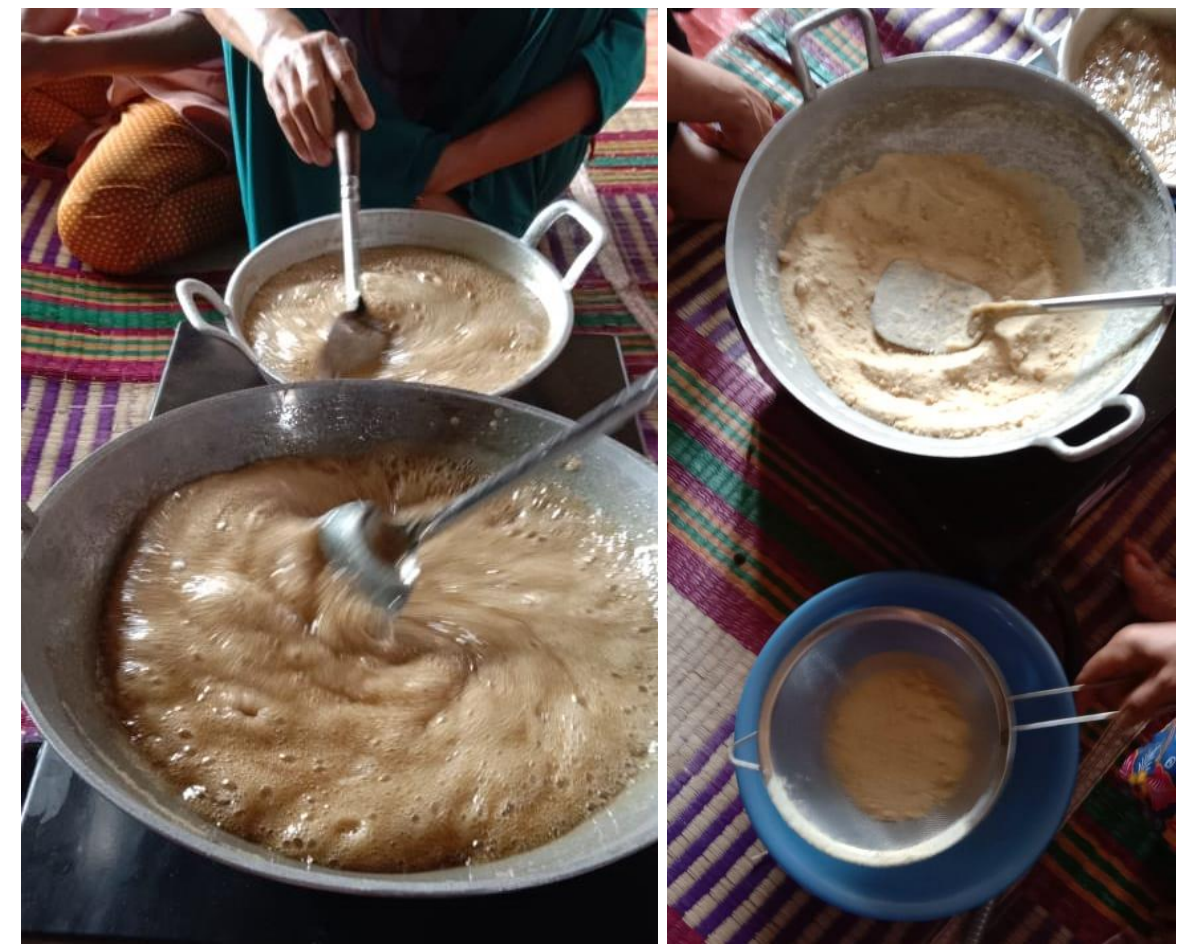

Gambar 4. Proses pengolahan jahe menjadi serbuk.

Adapun produk jahe merah hasil pengolahan masyarakat Desa Darmaraja Kecamatan Lumbung Kabupaten Ciamis dapat dilihat pada Gambar 5.

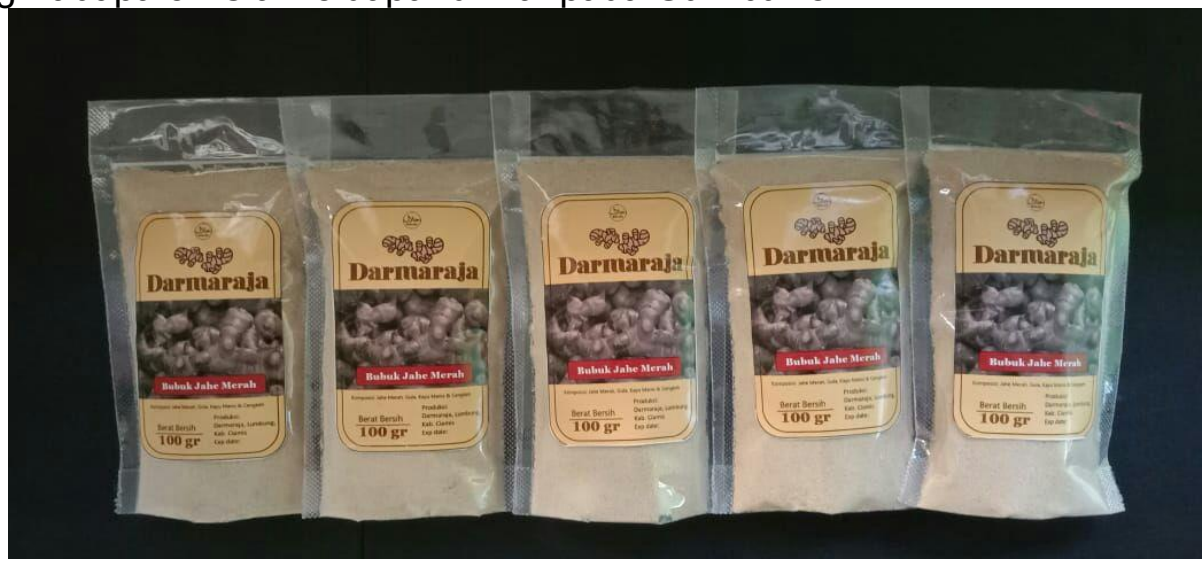

Gambar 5. Produk Serbuk Jahe Merah

\section{SIMPULAN DAN SARAN}

\section{A. SIMPULAN}

Secara keseluruhan hasil dari kegiatan pelatihan "Budidaya dan pengolahan tanaman jahe merah menggunakan teknologi bag culture pada masa new normal di Desa Darmaraja Kabupaten Ciamis" dapat dikatakan baik dan berhasil, hal ini dapat dilihat dari ketercapaian jumlah peserta pelatihan, ketercapaian tujuan pelatihan, ketercapaian materi pelatihan yang telah direncanakan dan ketercapaian dari peningkatan kemampuan peserta pelatihan dalam memahami tata cara budidaya dan pengolahan jahe merah menggunakan teknologi bag culture.

Kegiatan ini merupakan terobosan baru dalam mengakali keterbatasan lahan untuk bercocok tanam serta usaha peningkatan daya tahan tubuh masyarakat di masa pandemi Covid-19. Selain itu, kegiatan ini dapat mendorong kemandirian ekonomi mitra dengan usaha memberikan pengetahuan dalam budidaya tanaman jahe merah yang bernilai ekonomi tinggi. Mitra memberikan respons yang sangat positif terhadap kegiatan yang telah dilakukan dan menilai kegiatan ini sangat bermanfaat. 


\section{B. SARAN}

Pendampingan masyarakat perlu dilakukan secara serius dan berkelanjutan, terutama pelatihan mengenai penanaman tanaman yang mudah untuk ditanam dan memiliki nilai ekonomis yang bagus, seperti contohnya tanaman jahe merah. Pelatihan penanaman jahe merah kepada masyarakat Desa Darmaraja, Kecamatan Lumbung, Kabupaten Ciamis adalah sebagai upaya untuk memberikan pengetahuan serta praktik penanaman jahe merah terutama di masa New Normal ini. Memonitoring hasil kegiatan secara berkelanjutan bertujuan untuk mengamati dan mengetahui bagaimana perkembangan serta kemajuan yang telah dicapai masyarakat, selain itu untuk mengetahui kendala dan permasalahan yang terjadi .

\section{DAFTAR PUSTAKA}

Bahret, M., Steinberg, C. 2008. Spice Up YourSummer Greenhouse with Ginger. Tomatero Publication Inc.

BPS Kab. Ciamis. 2016. Lumbung Dalam Angka 2016. Lumbung: BPS Kab. Ciamis

Geta, E., Kifle, A. 2011. Production, Processing and Marketing of Ginger in Southern Ethiopia. Journal of Horticulture and Forestry. 3 (7): 207-213.

Inden, H., Asahira, T. and Hirano, A. 1988. Micropropagation of ginger. Acta Hort. 230:177184

Paul R. H, Francis Z. Boron. 2017. Calcium Deficiency causes Ginger Zingiber officinale Roscoe Diebackin Hawaii. Agri Res \& Tech: Open Access J; 9(1): 555755. DOI: 10.19080/ARTOAJ.2017.09.555755.

Rahman, H., Kishore, K., Denzongpa, R. 2009. Traditional Practices of Ginger Cultivation in Northeast India. Indian Journal of Traditional Knowledge. 8 (1): 23-28.

Stirling, A.M. 2002. Erwinia chrysanthemi, the cause of soft rot in ginger (Zingiber officinale) in Australia. Australasian Plant Pathology. 31(4):419-420.

Supriyanti, H. 2015. Untung Besar Budidaya Jahe Merah. Yogyakarta: Araska.

Triyono K, Sumarmi. 2018. Budidaya Tanaman Jahe di Desa Plesungan Kecamatan Gondangrejo Kab. Karanganyar Provinsi Jawa Tengah. ADIWIDYA, 2 (2) - November 2018.

Zuhro, F., \& Sukamto, D. S. 2018. Pengaruh Teknik Pemangkasan Batang Terhadap Produktivitas Jahe Gajah (Zingiber Officinale Var. Officinale) dengan Sistem Penanaman Bag Culture. Bioma: Jurnal Biologi dan Pembelajaran Biologi, 3(1). 